\title{
Screening of anti-dengue activity in methanolic extracts of medicinal plants
}

Leon IC Tang ${ }^{1 \dagger}$, Anna PK Ling ${ }^{2 *}{ }^{*}$, Rhun Y Koh ${ }^{2 \dagger}$, Soi M Chye ${ }^{2+}$ and Kenny GL Voon ${ }^{3+}$

\begin{abstract}
Background: Dengue fever regardless of its serotypes has been the most prevalent arthropod-borne viral diseases among the world population. The development of a dengue vaccine is complicated by the antibody-dependent enhancement effect. Thus, the development of a plant-based antiviral preparation promises a more potential alternative in combating dengue disease.

Methods: Present studies investigated the antiviral effects of standardised methanolic extracts of Andrographis paniculata, Citrus limon, Cymbopogon citratus, Momordica charantia, Ocimum sanctum and Pelargonium citrosum on dengue virus serotype 1 (DENV-1).

Results: O. sanctum contained $88.6 \%$ of total flavonoids content, an amount that was the highest among all the six plants tested while the least was detected in M. charantia. In this study, the maximum non-toxic dose (MNTD) of the six medicinal plants was determined by testing the methanolic extracts against Vero E6 cells in vitro. Studies also determined that the MNTD of methanolic extract was in the decreasing order of M. charantia $>C$. limon $>P$. citrosum, $O$. sanctum $>A$. paniculata $>C$. citratus. Antiviral assay based on cytopathic effects (CPE) denoted by degree of inhibition upon treating DENV1-infected Vero E6 cells with MNTD of six medicinal plants showed that $A$. paniculata has the most antiviral inhibitory effects followed by $M$. charantia. These results were further verified with an in vitro inhibition assay using $\mathrm{MTT}$, in which $113.0 \%$ and $98.0 \%$ of cell viability were recorded as opposed to $44.6 \%$ in DENV-1 infected cells. Although methanolic extracts of 0 . sanctum and C. citratus showed slight inhibition effect based on CPE, a significant inhibition was not reflected in MTT assay. Methanolic extracts of $C$. limon and $P$. citrosum did not prevent cytopathic effects or cell death from DENV-1.

Conclusions: The methanol extracts of $A$. paniculata and $M$. charantia possess the ability of inhibiting the activity of DENV-1 in in vitro assays. Both of these plants are worth to be further investigated and might be advantageous as an alternative for dengue treatment.
\end{abstract}

\section{Background}

Dengue disease regardless of its serotypes is transmitted from person to person by Aedes aegypti and Aedes albopictus mosquitoes in the domestic environment [1]. In the recent decade, dengue has re-emerged and with it being endemic in more than 110 countries, it has been the most prevalent arthropod-borne viral diseases in terms of morbidity and mortality [2]. Two fifths of the world populations are at risk, estimating around 100 million of dengue fever infections, 2.1 million cases of

\footnotetext{
* Correspondence: anna_ling@imu.edu.my

† Contributed equally

${ }^{2}$ Department of Human Biology, Faculty of Medicine and Health, International Medical University, Bukit Jalil, Kuala Lumpur, Malaysia Full list of author information is available at the end of the article
}

dengue hemorrhagic fever and 200 thousand deaths worldwide are caused by dengue every year. Despite extremely high rates of dengue for decades, Southeast Asia region still recorded an increase of 67\% from 19851989 to 2002-2006 [3]. Similarly, a total of 4.6-fold increase in dengue cases has also been reported in America over the three decades [3].

Dengue appears in two forms; the first classic dengue fever with symptoms that range from mild fever to high fever with retro-orbital pain, severe headaches, maculopapular rashes, muscle and joint pain. The other more severe form, Dengue Hemorrhagic Fever (DHF) and Dengue Shock Syndrome (DSS) may present with abdominal bleeding, hemorrhage and circulatory failure, which is fatal if without prompt and proper

\section{Biomed Central}


management [4]. There are four serologic types of dengue virus, DENV-1, $-2,-3$ and -4 . A primary infection with any of the four serotypes results in a lifelong immunity to that serotype, and temporary immunity to the others. However, this temporary immunity usually wanes after 6 months, at which point an individual is susceptible to the other three DENV serotypes [5]. The primary infection is most often asymptomatic, but sequential infections in the presence of heterologous dengue antibodies often leads to a more severe secondary infection causing DHF or DSS. Murrel et al. [5] attributed this to the antibody-dependent enhancement (ADE) effect. Studies on the outbreaks in endemic areas, such as South East Asia revealed that a primary infection with DENV-1 or DENV-3 frequently resulted in a more severe disease than if DENV-2 or DEV-4 were the primary infection [6].

With the rapid expansion of dengue disease in most tropical and subtropical areas of the world, it is crucial to develop effective prevention and control measures, including antiviral drugs and vaccines against dengue disease. However, the development of a dengue vaccine is complicated by the ADE effect, which happens when a child experiences a second dengue infection with a different serotype from the previous infection, causing DHF/DSS. The vaccine must not only protect against all four dengue serotypes but also must avoid inducing the ADE effect. Early studies have shown that extract from different parts of plants could provide good antiviral results as compared to their synthetic analogues [7]. As such, the development of a plant-based antiviral preparation promises a more potential alternative in combating dengue disease. Over the years, the World Health Organization (WHO) advocated that countries should interact with traditional medicine with a view to identify and exploit aspects that provide safe and effective remedies for ailments of antiviral. In addition, there are still no antiviral drugs being tested against dengue disease in any clinical trials. As such, present studies aimed to screen and determine the anti-dengue activity of methanolic extracts of Andrographis paniculata (Burm. f.) Nees, Citrus limon (L.) Burm. f., Cymbopogon citratus (DC.) Stapf, Momordica charantia L, Ocimum sanctum L. and Pelargonium citrosum, which have been used as folk medicine for dengue.

\section{Methods}

\section{Plant materials and extraction}

Andrographis paniculata, Ocimum sanctum, Pelargonium citrosum and Cymbopogon citratus plants were collected from Sungai Buluh, Selangor, Malaysia while Citrus limon and Momordica charantia were collected from Sibu, Sarawak and Sri Serdang, Selangor, respectively. The botanical identities of each plant were determined and authenticated by taxonomist from Institute of Bioscience, University Putra Malaysia. After the taxonomy identification, the plants were washed and cleaned prior to air drying at room temperature for one week. The whole aerial body of $A$. paniculata, O. sanctum, P. citrosum and C. citratus was blended and used. As for $C$. limon and $M$. charantia, the roots and entire fruits were utilised, respectively. Upon drying, $100 \mathrm{~g}$ of the plant materials were ground to powder and extracted consecutively with $500 \mathrm{~mL}$ of absolute methanol (Fisher Scientific, UK) for three to four days in dark condition. The resulting suspension was filtered and evaporated under reduced pressure at $50^{\circ} \mathrm{C}$ until dryness.

\section{Standardisation of extracts}

Standardisation of extracts was carried out based on the total flavanoids content of the extracts measured using aluminium chloride colourimetric assay as described by Pourmorad et al. [8]. For this assay, $0.1 \mathrm{mg}$ of extract was dissolved in $1 \mathrm{~mL}$ of methanol. The solution was then mixed with $0.1 \mathrm{mLof} 10 \%(\mathrm{v} / \mathrm{v})$ aluminium chloride (Sigma-Aldrich, USA), $0.1 \mathrm{~mL}$ of $1 \mathrm{M}$ potassium acetate (Sigma-Aldrich, USA) and $2.8 \mathrm{~mL}$ of distilled water. After 30 minutes of incubation at room temperature, the absorbance reading of the reaction mixture was measured at $415 \mathrm{~nm}$ using spectrophotometer (UV-Vis Spectrophotometer, Japan) with methanol as blank. A standard curve was constructed using quercetin (Sigma-Aldrich, USA) as the standard at the concentrations ranging from 50 to 200 $\mu \mathrm{g} / \mathrm{mL}$. Total flavonoids content of the extracts was then compared with the standard curve, expressed in mg quercetin equivalents per $100 \mathrm{~g}$ dry weight (mg QE/100 g DW) and further calculated as \% of total flavonoids content.

\section{Preparation of extracts}

For the cytotoxicity and antiviral assays, a stock solution was prepared by dissolving $2.0 \mathrm{~g}$ of extract in $100 \mathrm{~mL}$ of dimethyl sulfoxide (DMSO) (Sigma Aldrich, USA). The stock solution was filter sterilised $(0.20 \mu \mathrm{m}$ pore, Minisart) and further diluted with culture medium to the desired concentration for the assays.

\section{Preparation of medium}

Powdered Dulbecco's Modified Eagle's Medium (DMEM) (GIBCO, UK) was used in this study. A total of $3.7 \mathrm{~g}$ of sodium bicarbonate was added, dissolved with $1 \mathrm{~L}$ of ultrapure water and the $\mathrm{pH}$ of the medium was adjusted to 7.0. The medium was then filter sterilised using $0.22 \mu \mathrm{m}$ PES membrane filter (TPP, Switzerland) under vacuum condition.

\section{Maintenance of Vero E6 cells}

The cryopreserved Vero E6 cells were rapidly thawed at $37^{\circ} \mathrm{C}$ in a water bath. Cells were transferred carefully to 
$25 \mathrm{~cm}^{2}$ tissue culture flasks (Corning, USA) containing 4 $\mathrm{mL}$ of DMEM with $10 \%$ of Fetal Bovine Serum (FBS) (GIBCO, South America). Cells were then incubated at $37^{\circ} \mathrm{C}$ with $5 \% \mathrm{CO}_{2}$ for 2 to 3 days until confluent.

At $80-100 \%$ confluency, the cells were subcultured. The subculturing process was initiated by removing the used medium followed by rinsing the cells twice with Phosphate buffer solution (PBS) (MP Biomedical, France). Then, $1 \mathrm{~mL}$ of $0.25 \%$ trypsin-EDTA (GIBCO, Canada) was added and incubated for 5 to 10 minutes at $37^{\circ} \mathrm{C}$. After trypsinisation, $1 \mathrm{~mL}$ of fresh medium with $10 \%$ FBS was added and mixed. The mixture was then centrifuged for 10 minutes at $1500 \mathrm{rpm}$. The supernatant was discarded while the pellet was resuspended with $2 \mathrm{~mL}$ of fresh medium and re-distributed into new tissue culture flask for further maintenance.

\section{Preparation of virus stock}

The serotype of dengue virus obtained from Makmal Kesihatan Awam Kebangsaan (MKAM), Malaysia was confirmed through Polymerase Chain Reaction (PCR) and sequencing. The PCR was conducted based on the protocols described by Liu et al. [9]. In brief, the nucleotide sequence ( $400 \mathrm{bp}$ ) of the dengue virus was amplified using the primers, AD3 5' CTGATTTCCATC CCGTA 3' and AD4 5' CATATGGGTTATTGGA TAGA 3'. The PCR products were then sequenced. The sequencing results were compared with the library sequences using Basic Local Alignment Search Tool (BLAST). Thus, the dengue virus obtained was confirmed to be of serotype 1 (DENV-1).

The stock of dengue virus was obtained by adding 1 $\mathrm{mL}$ of DENV-1 to confluent Vero E6 cells and gently shaken for 1 hour to maximise the viral adsorption to the cells. After which, $4 \mathrm{~mL}$ of fresh medium with $10 \%$ FBS was added prior to incubation at $37^{\circ} \mathrm{C}$ with $5 \% \mathrm{CO}_{2}$ for six to seven days. Supernatant was then collected and stored at $-80^{\circ} \mathrm{C}$. These were repeated for several times until adequate virus stock was collected.

\section{Determination of maximum non-toxic dose (MNTD)}

The in vitro cytotoxicity assay was carried out on the extracts to determine the MNTD on Vero E6 cells. The cytotoxicity assay was initiated by seeding $1.5 \times 10^{4}$ cells into 96 well flat-bottom plates (Corning, USA). A blank control (medium only) and cell control (cells only) were also plated. The plate was then incubated in $5 \% \mathrm{CO}_{2}$ humidified incubator (RS biotech, Galaxy S) for 24 hours. After 24 hours, the cells were treated with diluted stock extract at the concentrations ranging from 0.05 to $2.5 \mathrm{mg} / \mathrm{mL}$, and later further incubated at $37^{\circ} \mathrm{C}$ with $5 \%$ $\mathrm{CO}_{2}$.

After 96 hours, $20 \mu \mathrm{L}$ of 3-(4,5-Dimethylthiazol-2-yl)2,5-diphenyltetrazolium bromide (MTT) salt solution was added into each well and incubated for 4 hours. After 4 hours, the supernatant of the well was carefully removed. A total of $100 \mu \mathrm{L}$ of DMSO was added followed by continuous shaking for 10 minutes. The absorbance reading of each well was measured using microplate reader (Tecan, Austria) at $570 \mathrm{~nm}$. The percentage of cell viability and toxicity was further determined based on the absorbance readings.

\section{Determination of median tissue culture infective dose ( $\mathrm{TCID}_{50}$ )}

A total of $1.5 \times 10^{4}$ cells/well were seeded into 96-well plate and incubated at $37^{\circ} \mathrm{C}$ with $5 \% \mathrm{CO}_{2}$. After 24 hours, a total volume of $100 \mu \mathrm{L}$ of ten-fold serially diluted DENV-1 was inoculated into each well with 10 replicates for each dilution. Plates were further incubated at $37^{\circ} \mathrm{C}$ for 5 days, after which cytopathic effect (CPE) was observed microscopically under inverted microscope. To determine the $\mathrm{TCID}_{50}$ based on Karber method [10], the presence of CPE in each well was marked as ' + ', while its absence was marked as ' - . The proportion of wells with CPE in each serially diluted DENV-1 was calculated and the TCID 50 was estimated using the formula ' $\log \operatorname{TCID}_{50}=\mathrm{L}-\mathrm{d}(\mathrm{s}-0.5)$ ', whereby $\mathrm{L}=$ lowest dilution factor; $\mathrm{d}=$ difference between dilution steps; $s=$ sum of proportion. The value of $\mathrm{TCID}_{50}$ determined was applied in the antiviral assay.

\section{In vitro antiviral assay}

The in vitro antiviral assay was initiated by seeding $1.5 \times$ $10^{4}$ cells/well into each well of 96-well plate, and left to incubate at $37^{\circ} \mathrm{C}$ with $5 \% \mathrm{CO}_{2}$ for 24 hours. After 24 hours, the medium was removed and $100 \mu \mathrm{L}$ of each plant extract at its MNTD was added. After incubating for 1 hour, $100 \mu \mathrm{L}$ of DENV-1 at its $\mathrm{TCID}_{50}$ was added. The assay was also conducted with the controls, which included the cells alone, cells treated with extracts and cells with DENV-1. The 96-well plate was further incubated for five days, after which the CPE of the cells were observed under inverted microscope on a daily basis. The antiviral effect of each plant extract was assessed using a grading system as described by Kudi and Myint [11], whereby the degree of CPE inhibition upon treatment was marked at the following order: ' +++ +' represented a total inhibition, ' +++ ' for $75 \%$ inhibition, ' ++ ' for $50 \%$ inhibition, ' + ' for less than $50 \%$ inhibition, ' - ' as no inhibition. The antiviral assay for each plant extract was conducted in five replicates and repeated twice.

The potency of these extracts on DENV-1 inhibition were also further examined using MTT assay, in which the percentage of viability of cells alone, cells infected with DENV-1, and infected cells treated with extracts at 
MNTD were measured and compared. Statistical difference between treatments and positive control was analysed using unpaired $t$-test at $p$ value less than $0.05(p<$ $0.05)$. The test was performed using GraphPad InStat version 3.0.

\section{Results and discussion}

\section{Standardisation of extracts}

In this study, the methanol extracts of the six plants were standardised based on the total flavonoids content determined through aluminium chloride colourimetric assay.

Earlier observations confirmed that flavonoids in plants and their derivatives possess antiviral activity $[12,13]$. Thus, in this study, the methanolic extracts were standardised based on total flavonoids content prior to antiviral assay. Present study reported that total flavonoids content enfolded a total of $87 \%$ of the methanolic extract of $O$. sanctum (Table 1). Medicinally importance flavonoids identified in $O$. sanctum were orientin, vicenin and luteolin $[14,15]$. Orientin and vicenin are reported to have radical scavenging activity [16] while lutoelin is known to be anti-inflammatory agent and have therapeutic action against multiple sclerosis $[17,18]$. M. charantia possessed a total flavonoid content of $21.7 \%$, of which some of them could be luteolin, kampherol and quercetin [19]. A study by Lin \& Tang[20] obtained a total flavonoids content that was slightly lower, at a value of $15.0 \%$. This could be due to the age and geographical locations of the plants as well as the temperature used during extraction [21]. In this study, A. paniculata is another plant that recorded low amount of total flavonoids content. In A. paniculata, some flavonoids that have been isolated were 7-O-methylwogonin, apigenin, onysilin and 3,4-dicaffeoylquinic acid, which are anti-atherosclerotic [22].

Meanwhile, C. limon possessed an average amount of total flavonoids content (33\%) among the six plants studied. C. limon is a good source of flavonoids such as hesperidin, diosmin and eriocitrin [23]. Root bark from the Citrus spp. possessed the flavonoids; citrunobin, citflavanone and lonchocarpol-A [24]. Meanwhile, C.

Table 1 The total flavonoids content of six medicinal plants as determined through aluminium chloride colourimetric assay.

\begin{tabular}{cc}
\hline Plant & Total flavonoids content (\%) \\
\hline Momordica charantia & $21.7 \pm 10.9$ \\
Andrographis paniculata & $24.3 \pm 3.0$ \\
Citrus limon & $32.6 \pm 6.7$ \\
Cymbopogon citrates & $35.2 \pm 10.1$ \\
Pelargonium citrosum & $61.1 \pm 10.2$ \\
Ocimum sanctum & $88.6 \pm 21.4$ \\
\hline
\end{tabular}

citratus showed an average total flavonoids content of $34.2 \%$. Reported flavonoids isolated from C. citratus were luteolin, apigenin, homoorintine flavanoides and its 2 -O rhamnosil-limborientino $[25,26]$. Among the six plants studied, $P$. citrosum recorded a high percentage of total flavonoids content. The reason underlying high flavonoids content in methanolic extracts of $P$. citrosum is yet to be known as there is still a lack of investigation on the flavonoid compounds in this plant. Up to now, apart from the report on the presence of small amount of tannins and coumarins [27], most of the studies on $P$. citrosum have been focused on its main constituent, essential oils.

\section{Determination of maximum non-toxic dose (MNTD)}

Prior to evaluating the anti-dengue properties of six medicinal plants, their methanolic extracts were subjected to toxicity studies in order to determine the maximal dose, which could be non-toxic to the cells. In this study, the MNTD of the six medicinal plants was determined by testing the methanolic extracts against Vero E6 cells in vitro. The studies were initiated by using tenfold serially diluted methanolic extracts of each plant followed by further optimisation in order to achieve a specific cytotoxic concentration. The MNTD of each plant obtained through the optimization steps were presented in Figure 1.

In general, the cytotoxicity studies discovered that MNTD for methanolic extract of $M$. charantia was 0.20 $\mathrm{mg} / \mathrm{mL}$, a value which was the highest among all the six plants examined (Figure 1A). In contrast, MNTD of $C$. citratus was the lowest, that was at a minute concentration of $0.001 \mathrm{mg} / \mathrm{mL}$ (Figure 1B) whilst the plant from Acanthaceae family, A. paniculata recorded the second lowest MNTD $(0.050 \mathrm{mg} / \mathrm{mL})$ (Figure 1C). Studies also revealed that there was no significant difference in MNTD values for C. limon, $P$. citrosum and $O$. sanctum (Figures 1D-F), in which all the three extracts attained MNTD that was two times higher as compared to $A$. paniculata. In terms of the pattern of cytotoxity, the extracts of C. citratus, A. paniculata, C. limon and $M$. charantia showed steep rises of cytotoxicity and reached the toxic limits over a narrow concentration range. Among all the plants, C. citratus showed maximum cytotoxicity at $0.075 \mathrm{mg} / \mathrm{mL}$, indicating that it is the most cytotoxic plant. Meanwhile, $P$. citrosum and $O$. sanctum exhibited slow rises in cytotoxicity over a wide range of concentrations.

Cytotoxic studies are essential for estimating the therapeutic range of plant extract on mammalian cells. In the present studies, both $O$. sanctum and P. citrosum have the highest cytotoxic values $(1.5 \mathrm{mg} / \mathrm{mL}$ and 2.5 $\mathrm{mg} / \mathrm{mL}$, respectively). A high cytotoxic value indicated that these two plants were less toxic as compared to the 

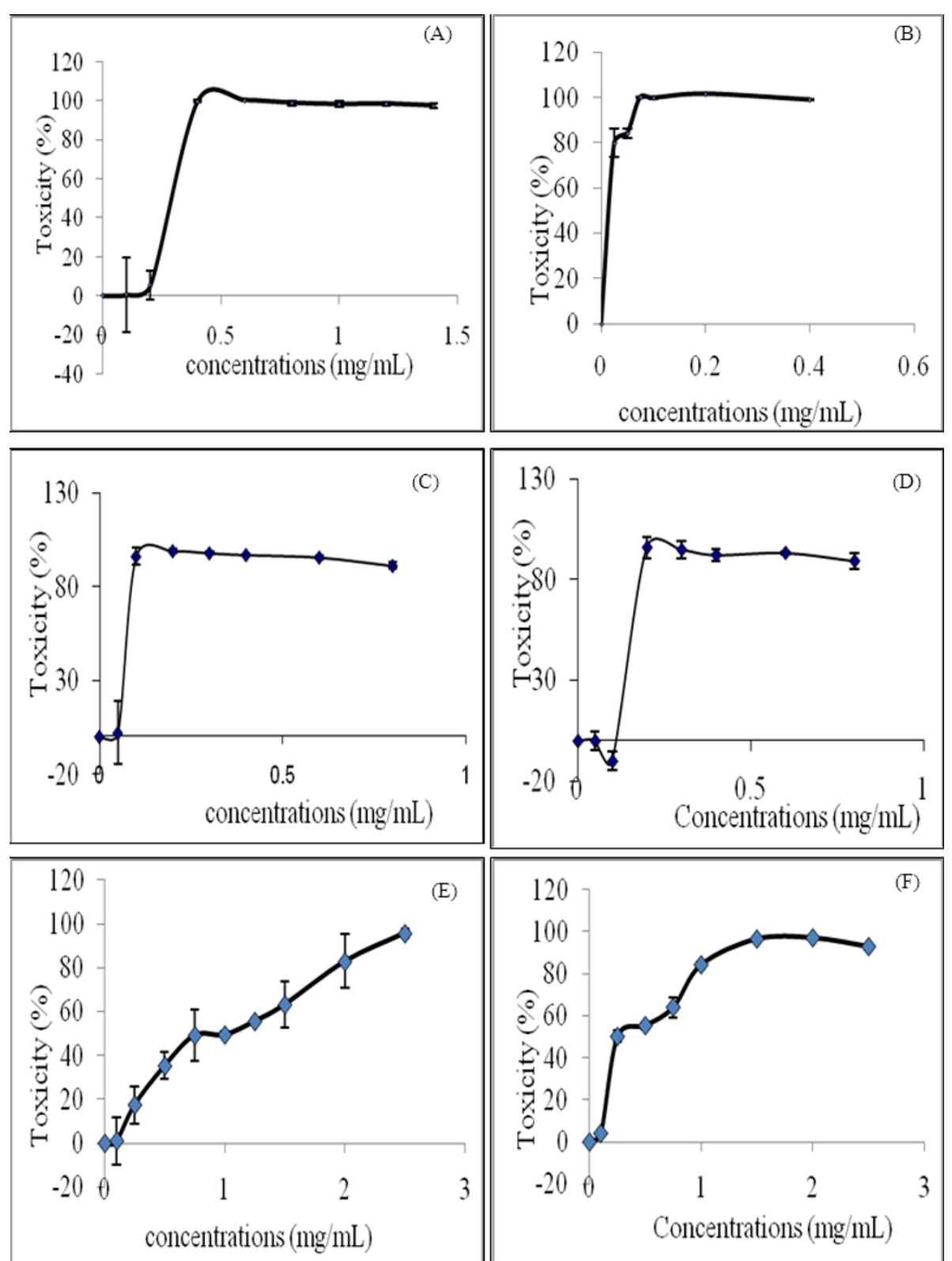

Figure 1 The percentage of toxicity of methanolic extracts of six plants on Vero E6 cells after incubated in vitro for 96 hours. (A) Momordica charantia (B) Cymbopogon citratus (C) Andrographis paniculata (D) Citrus limon (E) Pelargonium citrosum (F) Ocimum sanctum. The data shown are means \pm S.D. of two independent experiments performed in triplicates.

other four plants studied. As determined in this study, these two plants also recorded the highest amount of total flavonoids content. Hence, it is anticipated that the flavonoids present in the methanolic extract might have contributed to a high cytotoxic concentration. Flavanoids have been reported to possess antioxidative activities, such as to inhibit lipid peroxidation, chelate redoxactive metals and inhibit free-radical mediated events and even increasing resistance to DNA strand breakage $[28,29]$. These protect the cells by scavenging of free radicals that cause oxidative stress and can also induce changes in membrane to reduce membrane lipid and protein oxidation. Oteiza et al. [30] suggested that the flavonoids interact at the surface of bilayers to reduce the access of harmful oxidants, thus protecting the structure and function of membranes.

\section{In vitro antiviral assay}

In order to screen the anti-dengue properties of methanolic extracts of the six medicinal plants, in vitro 
antiviral assay was conducted. The antiviral assay was initiated using the MNTD of each plant extract against TCID $_{50}$. Prior to the qualitative observation of antiviral assay, a grading system was developed according to Kudi and Myint [11]. This system denoted the degree of inhibition seen under inverted microscope using the ' + ' symbol. The more '+' symbols signified a higher percentage of inhibition was observed whereas the '-'symbol indicated no inhibition or widespread cell death. Thus, ' ++++ ' represented a total inhibition, ' +++ ' for $75 \%$ inhibition, '++' for $50 \%$ inhibition, '+' for less than $50 \%$ inhibition and '-' as no inhibition was observed upon the treatment with methanolic extracts.

The Vero E6 cells grown in the tissue culture flasks with DMEM supplemented with 10\% FBS would form a monolayer sheet of cells. The morphology of Vero E6 cells were clearly visualised using an inverted light microscope. Under $200 \times$ magnification, the uninfected Vero E6 cells were polygonal in shape with well defined, black nuclei in the centre. The cytoplasm was shaded grey but the cell membranes were clearly demarcated with white lines surrounding the cells as shown in Figure 2 .

Apart from the uninfected cells, the DENV1-infected Vero E6 cells were also observed under inverted microscope. The various cytopathic effects (CPE) after 7 days post infection were examined at $100 \times, 200 \times$ and $400 \times$ magnifications as some CPE could be better viewed at different magnifications. From the observation, it was clearly shown that DENV1-infected cells showed CPE, which refers to the structural changes of the host cell due to viral infection. Generally, in comparison to the uninfected monolayer sheet of Vero E6 cells, DENV1infected cells appeared to have a congested and haphazard pattern (Figure 3A). Cytopathic effects included syncytia formation (Figure 3B) and cell lysis (Figure 3C). Syncytia formation could be due to viral fusion proteins being transported to the cell surface membranes, which later fused with neighbouring cells. In addition, blebbing of cells (Figure 3D), which referred to small detached remnants of apoptotic bodies that have undergone programmed cell death could also be observed upon DENV-1 infection.

Table 2 depicts the degree of inhibition on DENV-1 by the six medicinal plants. Among the six plants studied, A. paniculata showed the most antiviral inhibitory effects, that was $75 \%$ of inhibition. The methanolic extract of $A$. paniculata was able to maintain most of the normal cell morphologies without causing much CPE to the DENV-1 infected cells. The monolayer sheet of cells still remained normal with low amount of cells death or lysis as well as low percentage of CPE (Figure 4A). In addition to A. paniculata, M. charantia also exhibited moderate antiviral effects. Viable normal cells were observable in the background. Nevertheless, around $50 \%$ of the cells within the treatment showed CPE, which was indicated by the changes of shape of cells to spindle shaped (Figure 4B). The potency of

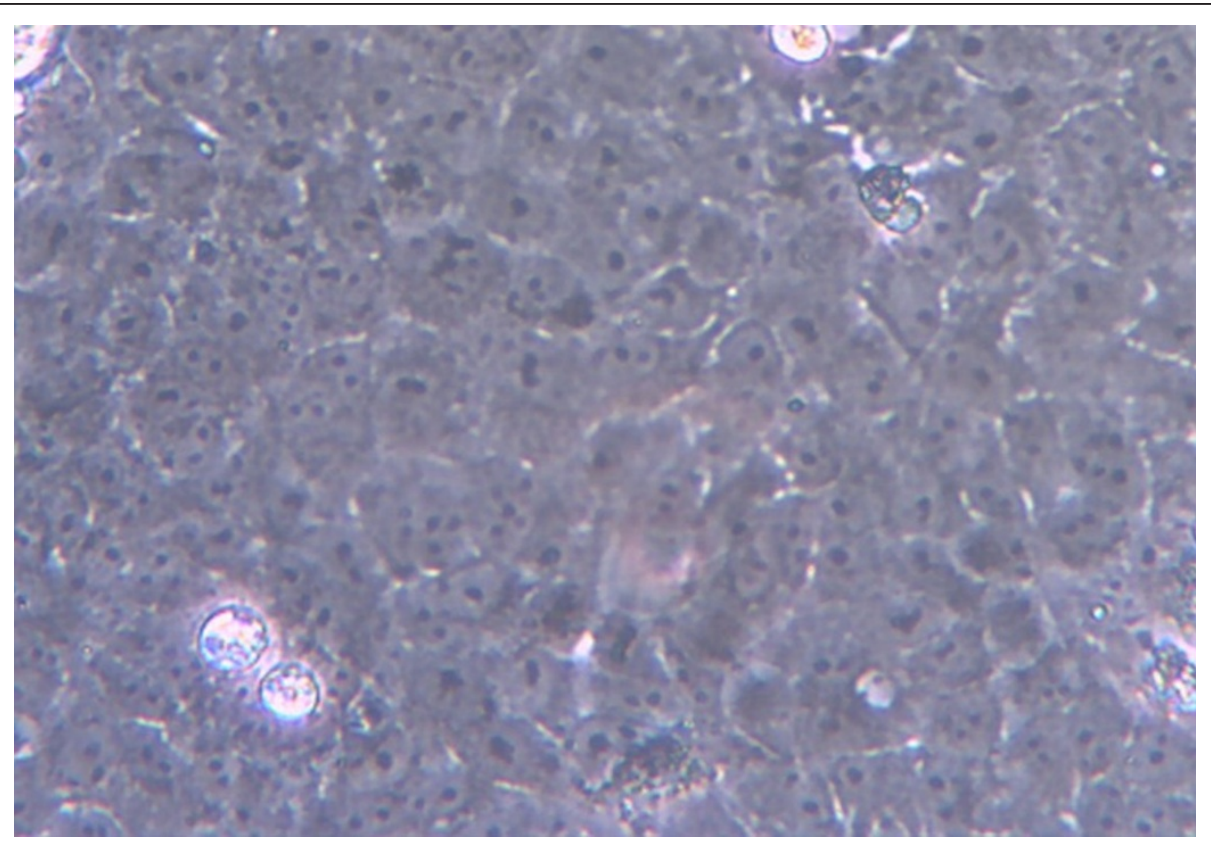

Figure 2 A monolayer sheet of uninfected Vero E6 cells. The normal cells were polygonal with well defined, black nuclei in the centre. The cytoplasm was shaded grey with the cell membranes were clearly demarcated with white lines surrounding the cells. The cells were viewed under inverted microscope at 200x magnification. 


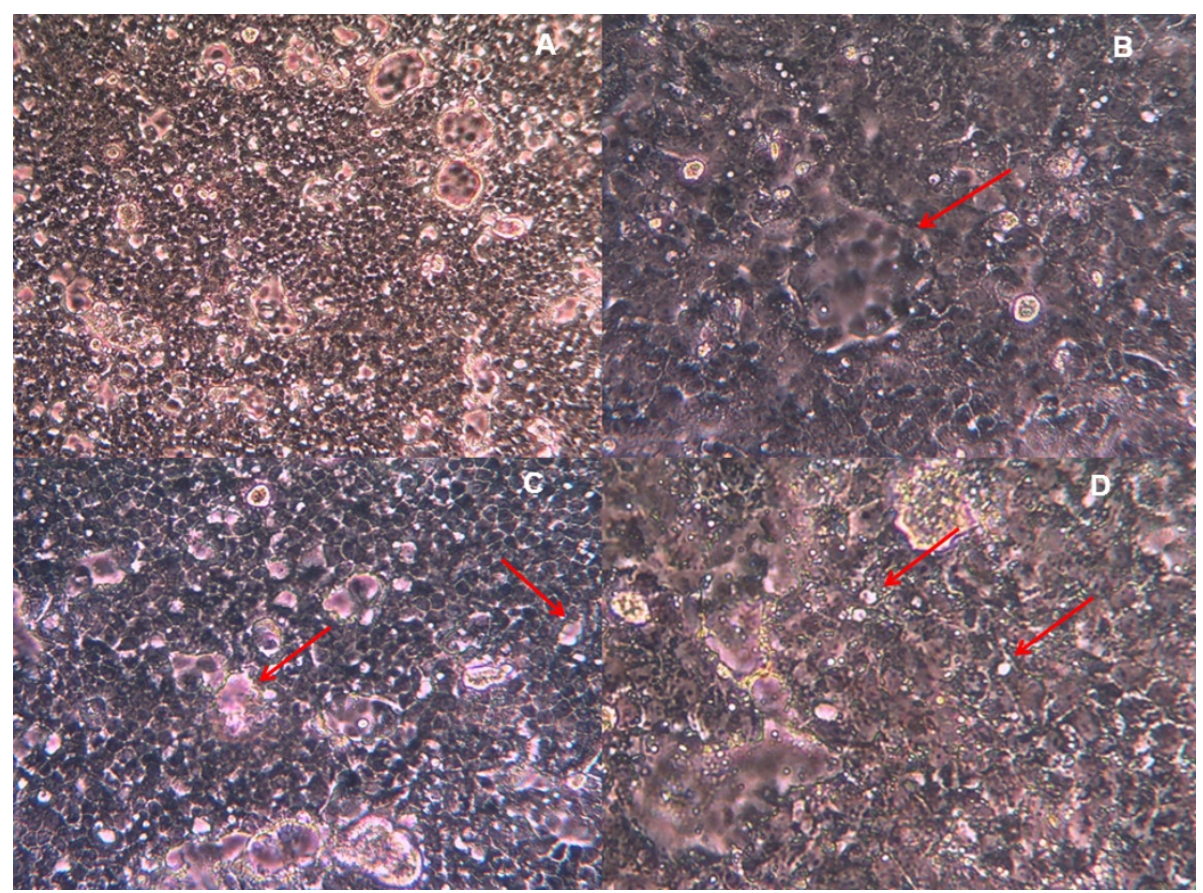

Figure 3 Various cytopathic effects observed in DENV-1-infected Vero E6 cells after 7 days post infection. (A) The monolayer sheet of cells at 100x magnification appeared to be congested and haphazard. (B) A typical syncythial giant cell formation or syncytia resulting from the fusion of a few cells infected with DENV-1 viewed at 200x magnification. The morphological changes appeared to be group of cells without a clear white demarcation of cell membrane. The cells located at the perimeter of the syncytia were observed clearly. (C) Areas of cell death or lysis are pointed out by the arrows. These small areas were clear of any cells and reflected the colour of the pink medium. (D) A higher magnification image $(400 \times)$ showing white dots called blebs.

these two extracts in inhibiting replication of DENV-1 was further confirmed through MTT assay, whereby the viability of cells treated with both A. paniculata and $M$. charantia extracts were not significantly affected upon infection with DENV-1 (Table 3).

Current preliminary screening study based on CPE also revealed that methanolic extracts of O. sanctum and C. citratus showed a low inhibition (less than 50\%) against DENV-1. Observation of CPE under the inverted microscope showed the presence of fragmented cells and debris (Figures 4C and 4D). Nevertheless, this was not in accordance with the MTT assay conducted as

Table 2 Antiviral assay based on cytopathic effects denoted by degree of inhibition upon treating the DENV1-infected Vero E6 cells with maximum non-toxic dose of six medicinal plants.

\begin{tabular}{cc}
\hline Plant species & Degree of inhibition \\
\hline Andrographis paniculata & +++ \\
Momordica charantia & ++ \\
Cymbopogn citratus & + \\
Ocimum sanctum & + \\
Citrus limon & - \\
Pelargonium citrosum & -
\end{tabular}

$+++75 \%$ inhibition, $++50 \%$ inhibition, $+<50 \%$ inhibition, - no inhibition only $48.0 \%$ and $32.0 \%$ of the cells treated with O. sanctum and C. citrates survived upon DENV-1 infection, respectively. The values recorded were not much differed from $44.6 \%$ achieved in the positive control that infected with DENV-1 (Table 3). The variation in findings based on CPE and MTT assay could be due to the fact that these extracts were able to inhibit the cytopatic effect without inhibiting the virus replication in Vero E6 cells. Among the six plant extracts tested, C. limon and $P$. citrosum did not prevent CPE or cell death from the effects of DENV-1. The normal polygonal-shaped cells were not visible followed by widespread of cell death, indicated by the amount of debris strewn across Figures 4E and 4F. Furthermore, cells treated with P. citrosum showed granulation and cell densing (pyknosis).

A. paniculata, C. limon, C. citratus, M. charantia, O. sanctum and $P$. citrosum have been traditionally known to possess antiviral activity. Out of the six plants tested, C. citratus, O. sanctum, $P$. citrosum and C. limon showed no anti-dengue activity even though some of their methanolic extracts exhibited high total flavonoids content. One of the possible explanations to this noninhibitory effect could be that there lies a relationship between the structure of the flavonoids and antiviral activity as described by Sanchez et al. [12]. It was found 


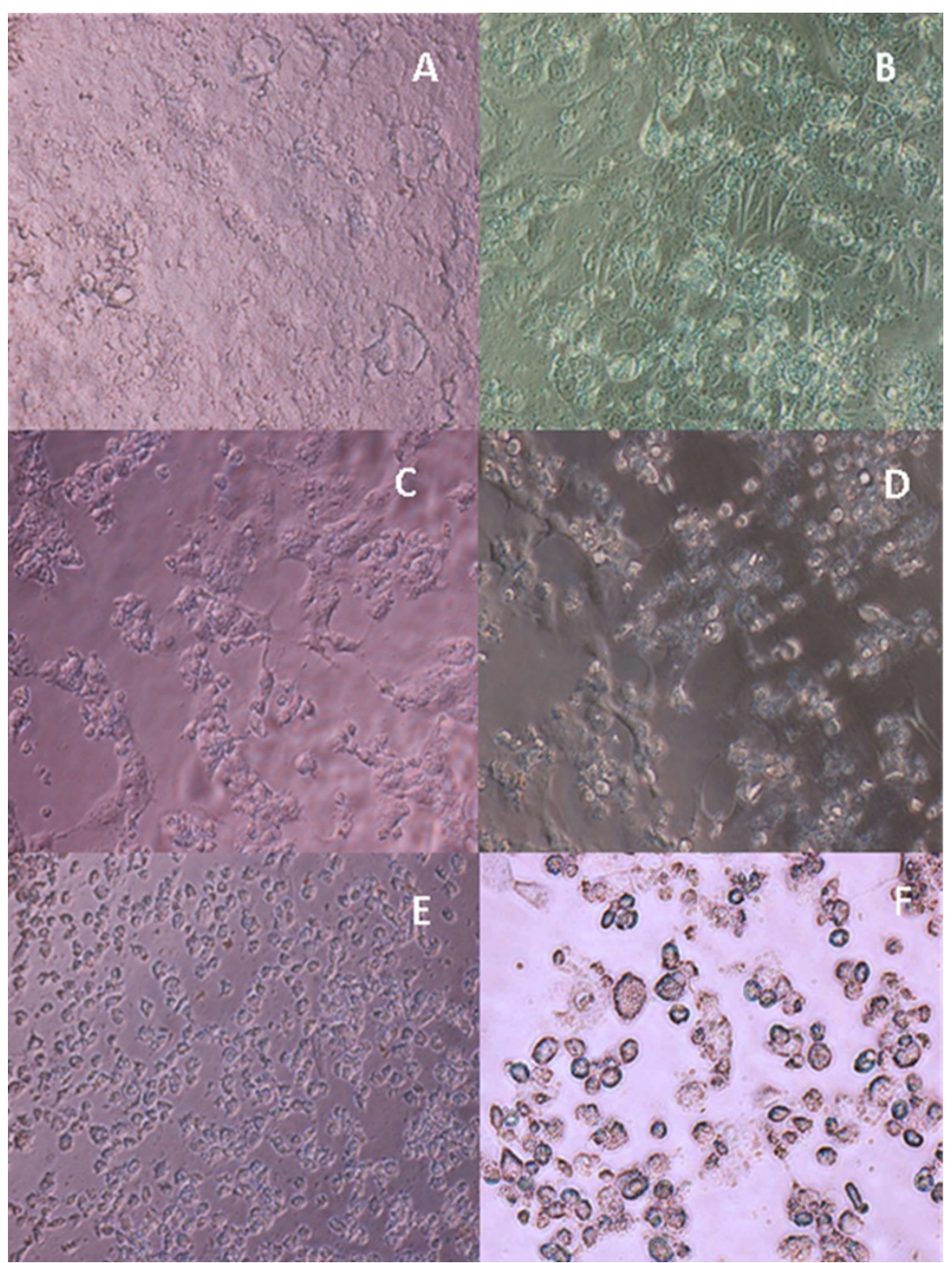

Figure 4 Morphological changes of DENV-1-infected Vero E6 cells treated with methanolic extracts of six medicinal plants at 7 days post infection. All the cells were viewed under inverted microscope at 200x magnification. (A) A. paniculata with75\% of inhibition. (B) M. charantia with 50\% of inhibition. (C) O. sanctum with less than 50\% inhibition. (D) C. citratus with less than 50\% inhibition (E) C. limon with no inhibition. Only cell fragments and debris were seen (F) P. citrosum with no inhibition. Granulation and cell densing were observed. The CPE for each treatment was compared with those of negative and positive controls shown in Figures 2 and 3, respectively.

in their comparative study that flavonoids with no prenyl side-chain totally lacked anti-dengue activity. $P$. citrosum and C. limon extracts showed obvious cell death when treated with DENV-1 infected control cells. A possible explanation to this result could be that the compounds present in these plants could have affected cell proliferation instead of virus replication [12], thus, preventing the cell sheet from regrowing after DENV-1 infected cell death.
In this preliminary screening study for anti-dengue agent, methanolic extract of $A$. paniculata and $M$. charantia was found to have high potential to be an antidengue agent, particularly towards DENV-1 serotype. $A$. paniculata extract showed a total of $75 \%$ of inhibition while $M$. charantia showed approximately $50 \%$ of inhibition on CPE upon infection with DENV-1. These findings suggested that the anti-dengue activity might be owing to the presence of flavonoid compounds or other 
Table 3 The percentage of cell viability as measured by MTT assay upon treating the DENV1-infected Vero E6 cells with maximum non-toxic dose of six medicinal plants.

\begin{tabular}{lc}
\hline Treatments & Cell viability (\%) \\
\hline Control (Untreated cells) & $100.00 \pm 10.50^{*}$ \\
Positive control (Cells infected with DENV-1) & $44.60 \pm 4.42$ \\
Andrographis paniculata & $113.00 \pm 4.65^{*}$ \\
Momordica charantia & $98.00 \pm 8.69^{*}$ \\
Cymbopogn citrates & $32.00 \pm 6.93$ \\
Ocimum sanctum & $48.00 \pm 7.16$ \\
Citrus limon & $52.00 \pm 7.54$ \\
Pelargonium citrosum & $41.40 \pm 2.75$ \\
\hline
\end{tabular}

The data shown are mean \pm S.D. ${ }^{i * \prime}$ denotes significant difference at $P<0.05$, compared to the positive control using unpaired $t$-test, performed by GraphPad Instat version 3.0.

compounds such as terpenes and polyphenols that were extractable by methanol. Various flavonoid compounds have been documented to possess antiviral properties. For instance, $M$. charantia that was reported to show anti-HSV-1, polio type 1, parainfluenza and respiratory syncytial virus activities [21] was found to contain flavonoids such as lutelin, kampherol and quercetin [19]. Flavonoids are able to inhibit viruses by inhibiting different pathways. Chang et al [31] disclosed that dehydroandrographolide succinic acid monoester (DASM) could interfere with cell fusion, thus preventing HIV from entering the cell. Alternately, certain flavonoids with potent antiHIV effects are capable of inhibiting virus associated reverse transcriptase and even cellular DNA or RNA polymerase [32].

Even though flavonoid compounds have been the main constituent of interest in search of anti-dengue agent, the role of diterpenes such as andrographolide, 14-deoxyandrographolide and 14-deoxy-11,12-didehydroandrographolide present in methanolic extract of $A$. paniculata [33] against DENV-1 should not be neglected. Andrographolide, and 14-deoxy-11,12-didehydroandrographolide have been reported to exhibit antiHIV activity [34]. Similarly, methanolic extract of $M$. charantia was found to contain terpenes, saponins and steroids $[35,36]$. In a related study, the methanolic extract of $M$. charantia was presumed to contain the major compound such as unglycosides terpenes [37]. However, there is a lack of literature to support that unglycoside terpenes cause any antiviral activity.

There are two probable pathways that could be the mode of antiviral action: 1) interfere with viral adsorption, and 2) inhibit viral replication. Schitzler et al. [38] noted that pre-treatment of the cells might give the cells protective effects against viruses by preventing viral adsorption. Furthermore, the dengue virus $\mathrm{E}$ protein is a potential target of inhibition due to its principal role in cell membrane adhesion [39]. As such, there is a possibility that the extract supplied might have blocked the $\mathrm{E}$ protein. Alternatively, the inhibitive event could have also occurred during viral replication. One stage of inhibition of viral replication by flavonoids was found using flavonoid SP-303, which showed a mode of antiviral action on DNA and RNA synthesis [32]. Another stage of inhibition of viral replication might be by blocking certain enzymes, such as an antiviral compound (NITD982) that inhibit an enzyme needed for pyrimidine biosynthesis [40]. Non-structural proteins are also potential targets of inhibition. For example, a study on STAT2, a component of type-1 interferon signalling pathway that is targeted for degradation once nNS5 is bound to it. The study showed that mouse STAT2 could restrict early dengue virus replication in vivo [41].

\section{Conclusions}

Studies on Andrographis paniculata and Momordica charantia that showed anti-dengue properties should be further conducted extensively. Isolation, purification and characterisation of the active compounds in order to discover the potential anti-dengue compounds should be carried out. Furthermore, investigations into the mode of action of anti-dengue activities by the active compounds can be done to provide more insight into inhibition of dengue adsorption and replication.

\section{List of abbreviations}

CPE: cytopathic effects; DENV-1: Dengue virus serotype 1; DMEM: Dulbecco's Modified Eagle's Medium; DMSO: dimethyl sulfoxide; FBS: Fetal Bovine Serum; MNTD: maximum non-toxic dose; TCID $_{50}$ : median tissue culture infective dose

\section{Acknowledgements}

This study was supported by International Medical University under BMS I022010(04). The Vero E6 cell line and DENV-1 were kindly provided by Makmal Kesihatan Awam Kebangsaan, Malaysia.

\section{Author details}

'School of Medical Sciences, Faculty of Medicine and Health, International Medical University, Bukit Jalil, Kuala Lumpur, Malaysia. ${ }^{2}$ Department of Human Biology, Faculty of Medicine and Health, International Medical University, Bukit Jalil, Kuala Lumpur, Malaysia. ${ }^{3}$ Department of Pathology, Faculty of Medicine and Health, International Medical University, Bukit Jalil, Kuala Lumpur, Malaysia.

\section{Authors' contributions}

APKL participated in the design and coordination of the study, carried out the extraction and standardization studies and edited the manuscript. LICT carried out the extraction and standardization studies, participated in the cytotoxicity and anti-viral assay and drafted the manuscript. RYK helped in the design of cytotoxicity and antiviral assay. SMC participated in the design and anti-viral assay. KGLV participated in the PCR and sequencing studies. All authors read and approved the final manuscript.

\section{Competing interests}

The authors declare that they have no competing interests.

Received: 14 June 2011 Accepted: 13 January 2012

Published: 13 January 2012 


\section{References}

1. Halstead SB: Dengue virus - Mosquito interactions. Annu Rev Entomol 2008, 53:273-291.

2. Guzman MG, Kouri G: Dengue diagnosis, advances and challenges. Int $J$ Infect Dis 2004, 8:69-80.

3. Gibbons RV: Dengue conundrums. Int J Antimicrob Agents 2010, 365 S36-S39.

4. Gubler DJ: Dengue and dengue hemorrhagic fever. Clin Microbiol Rev $1998,11: 480-96$

5. Murrell S, Wu SC, Butler M: Review of dengue virus and the development of a vaccine. Biotechnol Adv 2011, 29:239-247.

6. Vaughn DW, Green S, Kalayanarooj S, Innis BL, Nimmannitya S, Suntayakorn S, Rothman AL, Ennis FA, Nisalak A: Dengue in the early febrile phase: viremia and antibody responses. J Infect Dis 1997, 176:322-330.

7. Chiang LC, Ng LT, Cheng PW, Chiang W, Lin CC: Antiviral activities of extracts and selected pure constituents of Ocimum basilicum. Clin Exp Pharmacol Physiol 2005, 32:811-816.

8. Pourmorad F, Hosseinimehr SJ, Shahabimajd N: Antioxidant activity, phenol and flavonoid contents of some selected Iranian medicinal plants. Afr J Biotechnol 2006, 5:1142-1145.

9. Liu HS, Tzeng HC, Chen CC: Monitoring the CDNA synthesis of dengue-2 virus by RT PCR. / Virol Methods 1995, 51:55-59.

10. Gray J: From assays for virus infection. In Virus culture: a practical approach. Edited by: Cann AJ. New York: Oxford University Press; 1999:81-84.

11. Kudi AC, Myint MS: Antiviral activity of some Nigerian medicinal plant extracts. J Ethnopharmocol 1999, 68:289-294

12. Sanchez I, Gomez-Garibay F, Taboada J, Ruiz BH: Antiviral effect of flavonoids on the dengue virus. Phytother Res 2000, 14:89-92.

13. Ozcelik B, Kartal M, Orhan I: Cytotoxicity, antiviral and antimicrobial activities of alkaloids, flavonoids, and phenolic acids. Pharm Biol 2011 49:396-402.

14. Devi PU, Bisht KS, Vinitha M: A comparative study of radioprotection by Ocimum flavonoids and synthetic aminothiol protectors in the mouse. Br J Radiol 1998, 71:782-784.

15. Anandjiwala S, Kalola J, Rajani M: Quantification of eugenol, luteolin, ursolic acid, and oleanolic acid in black (Krishna Tulasi) and green (Sri Tulasi) varieties of Ocimum sanctum Linn. using high-performance thinlayer chromatography. J AOAC Int 2006, 89:1467-1474.

16. Uma DP, Ganasoundari A, Rao BS, Srinivasan KK: In vivo radioprotection by ocimum flavonoids: survival of mice. Radiat Res 1999, 151:74-78

17. Hilgard PSR: Heparan sulfate proteoglycans initiate dengue virus infection of hepatocyte. Hepatology 2000, 32:1069-1077.

18. Theoharides: Luteolin as a Therapeutic Option for Multiple Sclerosis. Neuroinflammation 2009, 6:29.

19. Mala Agarwal RK: Studies on flavonoid production using in vitro cultures of Momordica charantia. Indian J Biotechnol 2007, 6:277-279.

20. Lin JY, Tang CY: Determination of total phenolic and flavonoid contents in selected fruits and vegetables, as well as their stimulatory effects on mouse splenocyte proliferation. Food Chem 2007, 101:140-147

21. Kaul TN, Middleton E Jr, Ogra PL: Antiviral effect of flavonoids on human viruses. J Med Virol 1985, 15:71-79.

22. Chao WW, Lin BF: Isolation and identification of bioactive compounds in Andrographis paniculata (Chuanxinlian). Chin Med 2010, 5:17.

23. Fuster MD: Citrus Flavonoids. Distribution, modulation by phytorregulators and their possible physiological function. PhD. University of Murcia. Spain 1997.

24. Wu TS: Flavonoids from root bark of Citrus sinensis and C. nobilis. Phytochem 1989, 28:3558-3560.

25. Negrelle RRB, Gomes EC: Cymbopogon citratus (DC) Stapf: Chemical composition and biological activities. Rev Bras PI Med 2007, 9:80-92.

26. De Matouschek: Phytochemical studies on non-volatile constituents of Cymbopogon citratus (DC.) Stapf grown in Morocco. Pharm Acta Helv 1991, 66:242-245.

27. Meyers M: Pelargoniums: An Herb Society of America Guide. The Herb Society of America 2006.

28. Heim KE, Tagliaferro AR, Bobilya DJ: Flavonoid antioxidants: chemistry metabolism and structure-activity relationships. J Nutr Biochem 2002, 13:572-584.
29. Boyle SP, Dobson VL, Duthie SJ, Kyle JA, Collins AR: Absorption and DNA protective effects of flavonoid glycosides from an onion meal. Eur J Nutr 2000, 39:213-223.

30. Oteiza PIEA, Verstraeten SV, Keen CL, Fraga CG: Flavonoid-membrane interactions: a protective role of flavonoids at the membrane surface? Clin Dev Immunol 2005, 12:19-25.

31. Chang RS, Chen GQ, Pan OC, Zhao ZL, Smith KM:

Dehydroandrographolide succinic acid monoester as an inhibitor against the human immunodeficiency virus. Proc Soc Exp Biol Med 1991 197:59-66.

32. Ono K, Nakane $\mathrm{H}$ : Mechanisms of inhibition of various cellular DNA and RNA polymerases by several flavonoids. J Biochem 1990, 108:609-613.

33. Kumar RA, Sridevi K, Kumar NV, Nanduri S, Rajagopal S: Anticancer and immunostimulatory compounds from Andrographis paniculata. $J$ Ethnopharmacol 2004, 92:291-295

34. Reddy VL, Reddy SM, Ravikanth V, Krishnaiah P, Goud TV, Rao TP, Ram TS, Gonnade RG, Bhadbhade M, Venkateswarlu Y: A new bis-andrographolide ether from Andrographis paniculata nees and evaluation of anti-HIV activity. Nat Prod Res 2005, 19:223-230.

35. Mwambete KD: The in vitro antimicrobial activity of fruit and leaf crude extracts of Momordica charantia: a Tanzania medicinal plant. Afr Health Sci 2009, 9:34-39.

36. Grover KY, Yadav SP: Pharmacologicla actions and potential uses if Momordica charantia: a review. J Ethnopharmacol 2004, 93:123-132.

37. Hayat Sholihin SA, Musthapa Iqbal, Qowiyah Atun: Kajian efek antihiperglikemia (antidiabet) fraksi dan komponen aktif buah paria (Momordica charantia Linn) serta penentuan kadar komponen aktif dengan metode HPLC.[http://penelitian.Ippm.upi.edu/detil/1168/KAJIANEFEK-HIPOGLIKEMIA-(ANTIDIABET)-FRAKSI-DAN-KOMPONEN-AKTIF-BUAHPARIA-(MOMORDICA-CHARANTIA-LINN.)-SERTA-PENENTUAN-KADARKOMPONEN-AKTIF-DENGAN-METODE-HPLC].

38. Schnitzler P, Schneider S, Stintzing FC, Carle R, Reichling J: Efficacy of an aqueous Pelargonium sidoides extract against herpesvirus. Phytomedicine 2008, 15:1108-1116.

39. Modis Y, Ogata S, Clements D, Harrison SC: Structure of the dengue virus envelope protein after membrane fusion. Nature 2004, 427:313-319.

40. Wang L, Chen RF, Liu JW, Lee IK, Lee CP, Kuo HC, Huang SK, Yang KD: DCSIGN (CD209) Promoter -336 A/G polymorphism is associated with dengue hemorrhagic fever and correlated to DC-SIGN expression and immune augmentation. PLoS Negl Trop Dis 2011, 5:934.

41. Ashour J, Morrison J, Laurent-Rolle M, Belicha-Villanueva A, Plumlee CR, Bernal-Rubio D, William KL, Harris E, Fernandez-Sesma A, Schindler C, Garcia-Sastre A: Mouse STAT2 restricts early dengue virus replication. Cell Host Microbe 2010, 8:410-421.

\section{Pre-publication history}

The pre-publication history for this paper can be accessed here: http://www.biomedcentral.com/1472-6882/12/3/prepub

\section{doi:10.1186/1472-6882-12-3}

Cite this article as: Tang et al:: Screening of anti-dengue activity in methanolic extracts of medicinal plants. BMC Complementary and

Alternative Medicine 2012 12:3.

\section{Submit your next manuscript to BioMed Central and take full advantage of:}

- Convenient online submission

- Thorough peer review

- No space constraints or color figure charges

- Immediate publication on acceptance

- Inclusion in PubMed, CAS, Scopus and Google Scholar

- Research which is freely available for redistribution 